\title{
MATEMATICS PAEDAGOGIC
}

Vol IV. No.1, September 2019, hlm. 66- 74

Available online at www.jurnal.una.ac.id/indeks/jmp

\section{PENINGKATAN KEMAMPUAN PEMAHAMAN KONSEP MATEMATIK MAHASISWA MELALUI PEMBELAJARAN PROBLEM POSSING}

\author{
Syahriani Sirait \\ Universitas Asahan \\ Email : syahrianisirait88@gmail.com
}

\begin{abstract}
The purpose of this study was to determine whether the increased ability to understand mathematical concepts of students taught with problem possing learning was higher than students taught with conventional learning. This research is a quasi-experimental study with the study population as all semester III students in Mathematics Education Study Program. The sample selection is done randomly, namely third semester students of class IIIa and IIIb Mathematics Education Study Program. The instrument used consisted of a concept comprehension ability test. The results showed that: Increased ability to understand mathematical concepts of students taught with problem possing learning is higher than students taught with conventional learning
\end{abstract}

Keywords: problem possing learning model, students' mathematical concept understanding ability

\begin{abstract}
Abstrak
Tujuan penelitian ini untuk mengetahui apakah peningkatan kemampuan pemahaman konsep matematik mahasiswa yang diajarkan dengan pembelajaran problem possing lebih tinggi daripada mahasiswa yang diajarkan dengan pembelajaran konvensional. Penelitian ini merupakan penelitian quasi eksperimen dengan populasi penelitian adalah seluruh mahasiswa semester III kelas di Prodi Pendidikan Matematika. Pemilihan sampel dilakukan secara acak yaitu mahasiswa semester III kelas IIIa dan IIIb Prodi Pendidikan Matematika . Instrumen yang digunakan terdiri dari tes kemampuan pemahaman konsep. Hasil penelitian menunjukkan bahwa: Peningkatan kemampuan pemahaman konsep matematik mahasiswa yang diajarkan dengan pembelajaran problem possing lebih tinggi daripada mahasiswa yang diajarkan dengan pembelajaran konvensional
\end{abstract}

Kata Kunci Model Pembelajaran problem possing, Kemampuan Pemahaman Konsep Matematik mahasiswa 
Vol IV. No.1, September 2019, hlm. 66- 74

Available online at www.jurnal.una.ac.id/indeks/jmp

\section{PENDAHULUAN}

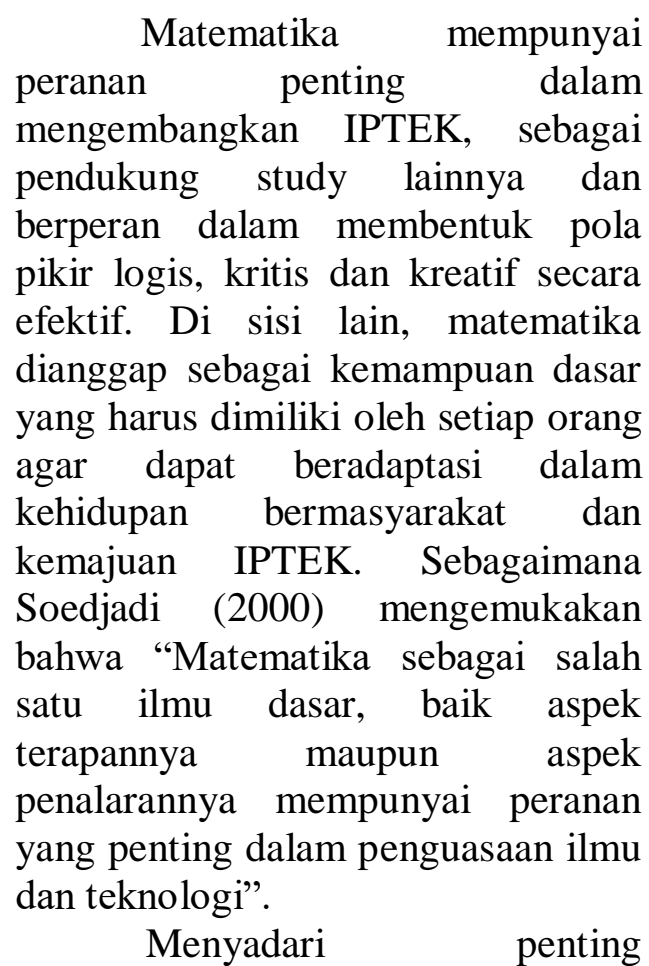
peranannya, pendidikan matematika perlu mengantisipasi tantangan masa depan yang semakin rumit dan kompleks. Karena itu pendidikan matematika harus mampu membekali mahasiswa keterampilan yang dapat menjawab permasalahan mendatang. Pentingnya pendidikan matematika itu menjadi dasar perguruan tinggi khususnya program studi pendidikan matematika untuk lebih dapat mempersiapkan calon guru bidang studi matematika untuk bisa memahami semua konsep dasar matematika. Menurut Rohana (2011) Dalam memahami konsep matematika diperlukan kemampuan generalisasi serta abstraksi yang cukup tinggi. Sedangkan saat ini penguasaan peserta didik terhadap materi konsep - konsep matematika masih lemah bahkan dipahami dengan keliru. Sebagaimana yang dikemukakan Ruseffendi (2006:156) bahwa terdapat banyak peserta didik yang setelah belajar matematika, tidak mampu memahami bahkan pada bagian yang paling sederhana sekalipun, banyak konsep yang dipahami secara keliru sehingga matematika dianggap sebagai ilmu yang sukar, ruwet, dan sulit. Padahal pemahaman konsep merupakan bagian yang paling penting dalam pembelajaran matematika seperti yang dinyatakan Zulkardi (2003) bahwa "mata pelajaran matematika menekankan pada konsep". Artinya dalam mempelajari matematika peserta didik harus memahami konsep matematika terlebih dahulu agar dapat menyelesaikan soal-soal dan mampu mengaplikasikan pembelajaran tersebut di dunia nyata. Konsep-konsep dalam matematika terorganisasikan secara sistematis, logis, dan hirarkis dari yang paling sederhana ke yang paling kompleks. Pemahaman terhadap konsep-konsep matematika merupakan dasar untuk belajar matematika secara bermakna.

Namun pada kenyataanya hasil pembelajaran di kelas masih sangat rendah. Mahasiswa masih belum mampu memahami keterkaitan antara materai yang satu dengan yang lainnya. Hal tersebut terlihat dari mata kuliah telaah matematika SMP. Materi dari mata kuliah tersebut mempelajari dan menalaah semua materi yang ada Sekolah Menengah Pertama. Seharusnya para mahasiswa sudah dapat memahami dengan baik karena materi tersebut sudah pernah mereka 
Jurnal

\section{MATEMATICS PAEDAGOGIC}

Vol IV. No.1, September 2019, hlm. 66- 74

Available online at www.jurnal.una.ac.id/indeks/jmp

pelajari pada saat mereka duduk di bangku sekolah menengah. Akan tetapi dari hasil pretes yang peneliti lakukan kepada mahasiswa diawal pembelajaran rata-rata mahasiswa hanya menjawab 50\% dari soal yang diberikan. Kenyataan tersebut disinyalir akibat dari pemahaman konsep mahasiswa yang masih rendah. Kemudian dari hasil wawancara diketahui bahwa pada saat mereka duduk dibangku sekolah strategi pembelajaran yang dilaksanakan oleh guru masih bersifat tradisional, yaitu siswa masih diperlakukan sebagai objek belajar dan guru lebih dominan berperan dalam pembelajaran dengan memberikan konsep-konsep atau prosedur-prosedur baku, sehingga pada pembelajaran ini hanya terjadi komunikasi satu arah.

Salah satu cara untuk mengatasi masalah tersebut adalah dosen diharapkan dapat menggunakan model pembelajaran yang dapat meningkatkan kineraja mahasiswa dalam tugas-tugas akademik, unggul dalam membantu mahasiswa memahami konsep-kosep yang sulit, dan membantu mahasiswa menumbuhkan kemampuan berpikir kritisnya dengan pemahaman konsep yang sebenarnya. Pembelajaran problem possing yang di kolaborasikan dengan pembelajaran kooperatif dapat memberikan keuntungan baik kepada mahasiswa yang memiliki kemampuan yang dapat dikelompokkan menjadi kelompok bawah maupun kelompok atas. Pembelajaran kooperatif yang di kolaborasikan dengan problem possing memberikan peluang kepada mahasiswa yang berbeda latar belakang dan kondisi untuk bekerja saling bergantung satu sama lain atas tugas-tugas bersama, dan melalui penggunaan struktur penghargaan kooperatif, belajar untuk menghargai satu sama lain.

Penerapan pembelajaran Problem Posing diharapkan dapat menciptakan situasi belajar yang menyenangkan, mendorong mahasiswa belajar dan memberikan kesempatan kepada mahasiswa untuk mengkonstruksi konsep-konsep yang dipelajarinya sehingga tercapainya hasil belajar mahasiswa yang baik. Dengan pemberian suatu masalah kepada mahasiswa akan menimbulkan rasa ingin tahunya, bagaimana cara menyelesaikanya, konsep yang bagaimana yang diperlukan untuk pemecahanyan dan metode apa yang tepat digunakan untuk penyelesainya. Hal tersebut akan mendorong mahasiswa menggunakan pengetahuan yang telah dimiliki dan mencari yang perlu diketahui untuk memecahkan masalah tersebut. Pembelajaran ini akan membuat mahasiswa lebih memahami konsep matematika dan mengetahui prosedur penyelesaian masalah sehingga mahasiswa terampil menyelesaikan soal-soal matematika serta kinerja dan ragam jawaban dari mahasiswa akan lebih baik.

Pembelajaran problem posing
membuat mahasiswa menjadi pembelajar yang mandiri, artinya ketika mahasiswa belajar, maka mahasiswa dapat memilih strategi belajar yang sesuai, terampil menggunakan strategi tersebut untuk belajar dan mampu mengontrol proses belajarnya, serta termotivasi 
Jurnal

\section{MATEMATICS PAEDAGOGIC}

Vol IV. No.1, September 2019, hlm. 66- 74

Available online at www.jurnal.una.ac.id/indeks/jmp

untuk menyelesaikan belajarnya itu (Depdiknas: 2003). Conny (dalam Sitorus: 2010) menyatakan bahwa satu prinsip mengaktifkan mahasiswa dalam belajar adalah prinsip belajar sambil bekerja. Dengan pembelajaran problem posing akan mengantarkan mahasiswa untuk memahami konsep materi pelajaran dan mengetahui prosedur pemecahan masalah dimulai dari belajar dan bekerja pada situasi masalah yang diberikan diawal pembelajaran, sehingga mahasiswa memperoleh kebebasan untuk berpikir mencari penyelesaianya dari masalah yang diberikan. Melalui pengalaman belajar yang diperoleh mahasiswa melalui kegiatan bekerja, mencari dan menemukan sendiri tidak akan mudah melupakannya.

Berdasarkan hal tersebut di atas, penulis tertarik untuk mengadakan penelitian tentang penerapan pembelajaran problem posing yang diperkirakan dapat meningkatkan pemahaman konsep dan pengetahuan prosedural matematika mahasiswa, sebab dalam pembelajaran ini dimulai dengan melakukan pemecahan masalah yang mendorong mahasiswa untuk aktif dalam melakukan penyelidikan dan penemuan. Di samping itu, mahasiswa dapat saling berdiskusi untuk menyelesaikan masalah maka diharapkan dapat meningkatkan keterampilan sosial mahasiswa dan jawaban yang diberikan mahasiswa lebih lengkap dengan adanya saling membantu dalam menyelesaikan permasalahan. Sebagai pembanding dari aplikasi pembelajaran problem posing akan dilihat juga sejauh mana pemahaman konsep dan pengetahuan prosedural matematika mahasiswa dengan pembelajaran biasa.

Beberapa hasil publikasi dari peneliti telah menunjukkan dampak positif dari penggunaan model pembelajaran problem possing. Berdasarkan hasil penelitian $\mathrm{N}$ Apriliani (2018) bahwa peningkatan kemampuan pemecahan masalah matematis siswa yang memperoleh pembelajaran matematika dengan menggunakan model pembelajaran Problem Posing lebih tinggi daripada siswa yang memperoleh model pembelajaran konvensional. Kemudian juano (2018) dengan judul pengaruh pembelajaran problem posing terhadap kemampuan berpikir kritis dan komunikasi matematis dan hasil penelitiannya yaitu terdapat pengaruh antara pembelajaran problem posing dan terhadap kemampuan berpikir kritis dan kemampuan komunikasi matematis. Dapat disimpulkan bahwa pembelajaran problem possing berpengaruh terhadap kemampuan matematik peserta belajar baikn itu siswa atapun mahasiswa.

Dari uraian d iatas, peneliti merasa penerapan pembelajaran pada setiap proses pembelajaranba sangatlah penting, maka peneliti mencoba mengkaji peningkatan kemampuan pemahaman konsep matematik mahasiswa dengan menggunakan pembelajaran problem possing.

\section{METODE}

Populasi dalam penelitian ini adalah seluruh mahasiswa semester III Prodi pendidikan matematika Universitas Asahan. Sampel yang terpilih dipilih secara acak yaitu 


\section{MATEMATICS PAEDAGOGIC}

Vol IV. No.1, September 2019, hlm. 66- 74

Available online at www.jurnal.una.ac.id/indeks/jmp

mahasiswa semester III kelas III-a dan III-b.Kemudian dilakukan undian sekali lagi untuk memilih kelompok pembelajaran problem possing yaitu kels III-a dan kelompok pembelajaran konvensional kelas III-b.

Jenis penelitian ini adalah quasi experiment (eksperimen semu)

\section{Kelompok}

$$
\begin{aligned}
& \text { Random : III-a ( Kel.Eksperimen) } \\
& \text { Random : III-b ( Kel. Kontrol ) }
\end{aligned}
$$

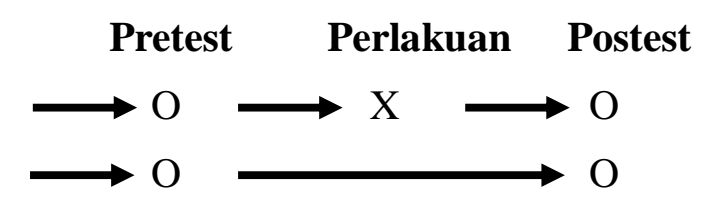

sebab kelas yang digunakan telah terbentuk sebelumnya. Desain yang digunakan dalam penelitian ini adalah desain eksperimen dengan kelompok kontrol pretes dan postes :

Keterangan:

X : Perlakuan berupa Pembelajaran problem possing

$\mathrm{O}$ : Pretest dan postes kemampuan pemahaman konsep matematik mahasiswa.

Instrumen pengumpulan data melalui tes kemampuan pemahaman konsep mahasiswa. Data yang diperoleh melalui tes, digunakan untuk melihat peningkatan kemampuan pemahaman matematik mahasiswa. Analisis statistik yang digunakan uji t.

\section{HASIL DAN PEMBAHASAN}

Tes kemampuan pemahaman konsep dilakukan 2(dua) kali yaitu pretes (sebelum dilakukan pembelajaran) dan postes (setelah pembelajaran). Untuk tes kemampuan pemahaman konsep terdiri dari 5 butir soal baik pretes maupun postes. Setelah dilakukan pengolahan data pretes, postes dan N-Gain kemampuan pemahaman konsep, diperoleh skor terendah ( $\left.\chi_{\text {min }}\right)$, skor tertinggi ( $\chi_{\text {maks }}$ ), skor rata-rata ( $\chi_{\text {rata-rata }}$ ) dan standar deviasi (SD). Untuk lebih jelasnya diuraikan berikut ini.

\section{Deskripsi Hasil Tes Kemampuan Pemahaman Konsep Kelas Eksperimen}

Secara garis besar untuk hasil tes kemampuan pemahaman konsep matematika pada kelas ekperimen dapat dilihat pada tabel berikut ini:

Tabel 1. Hasil Tes Kemampuan Pemahaman konsep Matematika Kelas Eksperimen

\begin{tabular}{cccccc}
\hline $\begin{array}{c}\text { Kelas } \\
\text { Eksperimen }\end{array}$ & $\begin{array}{c}\text { Skor } \\
\text { Maksi } \\
\text { mal }\end{array}$ & $\boldsymbol{X}_{\text {maks }}$ & $\boldsymbol{X}_{\text {min }}$ & $\bar{X}$ & SD \\
\hline Pretes & 14 & 8 & 0 & 2.23 & 2.22 \\
\hline
\end{tabular}




\section{MATEMATICS PAEDAGOGIC}

Vol IV. No.1, September 2019, hlm. 66- 74

Available online at www.jurnal.una.ac.id/indeks/jmp

\begin{tabular}{cccccc}
\hline Postes & 14 & 14 & 9 & 11.55 & 1.63 \\
N-Gain & 14 & 1 & 0.583 & 0.80 & 0.13 \\
\hline
\end{tabular}

Sedangkan agar lebih jelas perbedaan dari pretes, postes dan $\mathrm{N}$-gain dari kemampuan pemahaman konsep matematika untuk kelas eksperimen dapat dilihat pada diagram batang berikut ini:

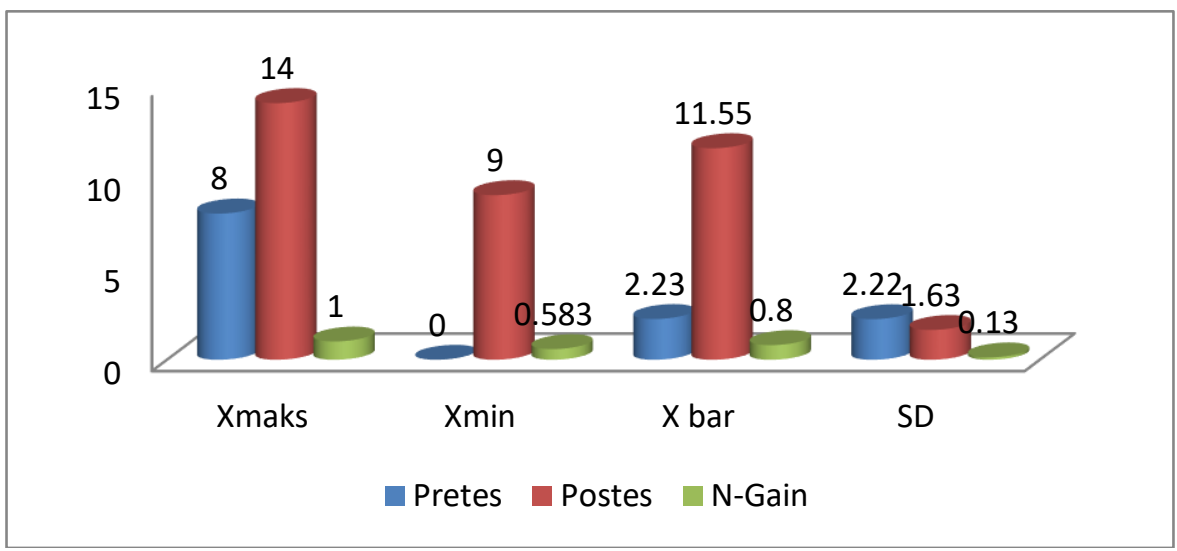

Setelah dilakukan pretest dan postest kepada mahasiswa diperoleh N-Gain masing-masing kelas untuk melihat apakah peningkatan kemampuan pemahaman konsep matematik mahasiswa yang diajarkan melalui pembelajaran problem possing lebih tinggi daripada mahasiswa yang diajarkan melalui pembelajaran konvensional.Rata-rata N-Gain kemampuan pemahaman konsep matematik mahasiswa pada kelas eksperimen sebesar 0,8 dan pada kelas kontrol sebesar 0,45. Untuk mengetahui apakah peningkatan kemampuan pemahaman konsep matematik mahasiswa yang diajarkan melalui pembelajaran problem possing lebih tinggi daripada mahasiswa yang diajarkan melalui pembelajaran konvensional digunakan uji t. Dari data N-gain kemampuan pemahaman konsep matematik mahasiswa diketahui data berdistribusi normal dan homogen.

\section{Hasil Uji Normalitas N-Gain kemampuan pemahaman konsep matematik Kelas Eksperimen dan Kelas Kontrol}

\begin{tabular}{|c|c|c|c|c|c|c|c|}
\hline \multicolumn{8}{|c|}{ Tests of Normality } \\
\hline & \multirow{2}{*}{ Faktor } & \multicolumn{3}{|c|}{ Kolmogorov-Smirnov } & \multicolumn{3}{|c|}{ Shapiro-Wilk } \\
\hline & & Statistic & df & Sig. & Statistic & $d f$ & Sig. \\
\hline \multirow{2}{*}{$\begin{array}{l}\text { Pemahaman } \\
\text { Konsep }\end{array}$} & Eksperimen & .133 & 40 & .071 & .940 & 40 & .035 \\
\hline & Kontrol & .111 & 40 & $.200^{*}$ & .965 & 40 & .254 \\
\hline
\end{tabular}




\section{MATEMATICS PAEDAGOGIC}

Vol IV. No.1, September 2019, hlm. 66- 74

Available online at www.jurnal.una.ac.id/indeks/jmp

\section{Hasil Uji Homogenitas kemampuan pemahaman konsep matematik} N-Gain Kelas Eksperimen Dan Kelas Kontrol

\begin{tabular}{|c|c|c|c|}
\hline \multicolumn{4}{|c|}{ Test of Homogeneity of Variances } \\
\hline \multicolumn{4}{|c|}{ Pemahaman Konsep } \\
\hline Levene Statistic & df1 & df2 & Sig. \\
\hline .350 & 1 & 78 & .556 \\
\hline
\end{tabular}

\section{Deskripsi Uji Perbedaan Rata-Rata N-Gain Kemampuan Pemahaman Konsep Matematika Mahasiswa}

\begin{tabular}{|c|c|c|c|c|c|c|c|c|}
\hline \multicolumn{9}{|c|}{ Independent Samples Test } \\
\hline & $\begin{array}{l}\text { Leven } \\
\text { for Eq } \\
\text { Vari }\end{array}$ & $\begin{array}{l}\text { 's Test } \\
\text { ality of } \\
\text { nces }\end{array}$ & \multicolumn{6}{|c|}{ t-test for Equality of Means } \\
\hline & & & & & & & $\begin{array}{r}95 \% \text { Cor } \\
\text { Interval } \\
\text { Differ }\end{array}$ & $\begin{array}{l}\text { idence } \\
\text { of the } \\
\text { nce }\end{array}$ \\
\hline & $\mathrm{F}$ & Sig. & df & $\begin{array}{l}\text { Sig. (2- } \\
\text { tailed) }\end{array}$ & $\begin{array}{c}\text { Mean } \\
\text { Difference }\end{array}$ & $\begin{array}{l}\text { Std. Error } \\
\text { Difference }\end{array}$ & Lower & Upper \\
\hline $\begin{array}{l}\text { Pemah Equal variances } \\
\text { aman assumed }\end{array}$ & .350 & .556 & 11.030 & .000 & .34762 & .03152 & .28488 & .41037 \\
\hline $\begin{array}{c}\text { Konsep Equal variances } \\
\text { not assumed }\end{array}$ & & & 11.03075 .679 & .000 & .34762 & .03152 & .28485 & .41040 \\
\hline
\end{tabular}

Berdasarkan hasil

perhitungan pada tabel $4.20 \mathrm{di}$ atas dengan menggunakan uji $\mathrm{t}$ pada taraf signifikansi $\alpha=0,05$ diperoleh $t_{\text {hitung }}$ sebesar 11,030 dengan nilai signifikansi 0,000 sedangkan $t_{\text {tabel }}$ sebesar 1,99. Karena $t_{\text {hitung }}>t_{\text {tabel }}$ $(11,030>1,99)$ dan signifikansi < $0,05(0,000<0,05)$, sehingga $\mathrm{H}_{0}$ ditolak. Maka dapat disimpulkan bahwa peningkatan Kemampuan paling berpengaruh terhadap kemampuan pemahaman konsep matematik mahasiswa. Tiap tahap dalam model pembelajaran problem possing memberi kontribusi terhadap peningkatan kemampuan mahasiswa. problem possing memberi kontribusi terhadap peningkatan kemampuan mahasiswa. Jadi, setiap tahapan
Pemahaman Konsep matematik mahasiswa yang diajarkan melalui pembelajaran problem possing lebih tinggi dari pada yang diajarkan melalui pembelajaran konvensional.

\section{PEMBAHASAN PENELITIAN}

\section{Faktor Pembelajaran}

Faktor pembelajaran merupakan salah satu hal yang dalam pembe;ajaran problem possing benar-benar diterapkan dalam proses pembelajaran untuk memperoleh hasil yang optimal. Peneliti selalu berkiling untuk memastikan mahasiswa mengerjakan LAS yang diberikan dan membantu setiap kesulitan mereka. Model pembelajaran problem posing pada 
Jurnal

\section{MATEMATICS PAEDAGOGIC}

Vol IV. No.1, September 2019, hlm. 66- 74

Available online at www.jurnal.una.ac.id/indeks/jmp

prinsipnya adalah suatu model pembelajaran yang mewajibkan para

\section{Kemampuan Pemahaman konsep}

Pemahaman konsep adalah pengetahuan yang terkait antara informasi yang terkandung pada konsep yang dipahami dengan skemata yang telah dimiliki sebelumnya". Pemahaman konsep dalam penelitian ini terdiri dari 5 indikator yaitu 1) Kemampuan menyatakan ulang sebuah konsep 2) mengklasifikasikan objek-objek menurut sifat-sifat tertentu; 3) Memberikan contoh dan bukan contoh dari konsep 4) menyajikan konsep dalam berbagai bentuk representasi matematik, 5 )Mengembangkan syarat perlu/syarat cukup suatu konsep.

Dari hasil penelitian didapat bahwa rata-rata skor pretest kemampuan pemahaman konsep mahasiswa yang memperoleh pembelajaran problem possing sebesar 2,23 dan pada mahasiswa yang memperoleh pembelajaran konvensional sebesar 2,75 kemudian setelah pembelajaran dilakukan hasil postest kemampuan pemahaman konsep mahasiswa yang diajarkan dengan pembelajaran problem possing sebesar 11, 5 dan hasil postest yang diajarkan dengan pembelajaran konvensional sebesar 7,83 . Kemudian $\mathrm{N}$-gain pemahaman konsep mahasiswa yang memperoleh pembelajaran problem possing sebesar 0,8 dan pada mahasiswa yang diajarkan dengan pembelajaran konvensional 0,45. diperoleh bahwa peningkatan kemampuan pemahaman konsep mahasiswa yang diajarkan dengan pembelejaran problem possing lebih tinggi mahasiswa untuk mengajukan soal sendiri melalui belajar soal.

daripada mahasiswa yang diajarkan dengan pembelajaran konvensional.

Berdasarkan pengujian dengan menggunakan uji t maka diperoleh kemampuan pemahaman konsep dengan nilai signifikan (sig) $\alpha=$ 0,000. Karena taraf nilai signifikan kemampuan pemahaman konsep lebih kecil dari $\alpha=0,05$, maka dapat disimpulkan bahwa peningkatan kemampuan pemahaman konsep mahasiswa yang diajarkan dengan pembelajaran problem possing lebih tinggi daripada mahasiswa yang diajarkan dengan pembelajaran konvensional.

\section{SIMPULAN}

Berdasarkan hasil analsis data dari lapangan tentang pengaruh pembelajaran problem possing terhadap kemampuan pemahaman konsep matematik mahasiswa, diperoleh beberapa kesimpulan yang merupakan jawaban atas petanyaan pada rumusan masalah, yaitu Peningkatan kemampuan pemahaman konsep matematik mahasiswa yang diajarkan melalui pembelajaran problem possing lebih tinggi dari pada yang diajarkan melalui pembelajaran konvensional

\section{SARAN}

Berdasarkan hasil penelitian dengan menerapkan pembelajaran problem possing, memberikan beberapa hal untuk perbaikan kedepannya. Untuk itu peneliti menyarankan kepada pihak-pihak tertentu yang berkepentingan 


\section{MATEMATICS PAEDAGOGIC}

Vol IV. No.1, September 2019, hlm. 66- 74

Available online at www.jurnal.una.ac.id/indeks/jmp

dengan hasil penelitian ini, diantaranya:

a. Untuk meningkatkan kemampuan pemahaman konsep matematik mahasiswa dosen dapat menggunakan pembelajaran problem possing terutama.

b. Dosen diharapkan perlu menambah wawasan tentang teori-teori pembelajaran yang lain (pembelajaran yang inovatif), dan dapat menerapkannya dalam pembelajaran.

c. Dalam setiap pembelajaran dosen harus menciptakan suasana belajar yang memberi kesempatan kepada mahasiswa untuk

\section{DAFTAR RUJUKAN}

Siti Rohana, 2011. Senam Vitalisasi

Otak Lebih Meningkatkan Fungsi Kognitif Kelompok

Lansia Daripada Senam

Lansia Di Balai Perlindungan

Sosial Propinsi Banten.

Zulkardi. 2003. "Pendidikan

Matematika di Indonesia:

Beberapa Permasalahan dan mengungkapkan gagasangagasan matematika dalam bahasa dan cara mereka sendiri, sehingga dalam belajar matematika mahasiswa menjadi berani berargumentasi, lebih percaya dan kreatif.

d. Pembelajaran problem possing umumnya memerlukan waktu yang banyak dalam pelaksaannya. Jadi, apabila ingin melanjutkan peneletian ini alokasi waktu harus diperhitungkan agar memperoleh hasil yang maksimal.

Banten: Fisioterapi Klinik Pancoran Mas.

Ruseffendi, E.T. (2006). Dasar-Dasar Matematika Modern dan Komputer Untuk Guru. Bandung : Tarsito Upaya Penyelesaiannya." Palembang: Unsri. 